Pietrzykowski M. (Ed.): Fostering Entrepreneurial and Sales Competencies in Higher Education.

Bogucki Wyd. Nauk., Poznań 2019. ISBN 978-83-7986-280-1

DOI: $10.12657 / 9788379862801-3$

\title{
Maciej Pietrzykowski
}

\section{Edutainment as an Innovative Form of Teaching Entrepreneurship}

\section{Introduction}

As stipulated in the Council Recommendation of 22 May 2018 on key competencies for lifelong learning, entrepreneurship has been recognized as one of the key competences. As mentioned in the document, the development of key competences, their validation and the provision of competence-oriented education, training and learning should be supported by establishing good practices for better support of educational staff in their tasks and improving their education, for updating assessment and validation methods and tools, and for introducing new and innovative forms of teaching and learning (European Union, 2018). The fourth industrial revolution that we face every day has a transformative impact on industry, the economy and society as a whole, thus also having a huge impact on education. Considering the dynamic changes in society and the rapid evolution of technology, education has to change and a revolution in teaching and learning methodologies is required to adopt a type of learning outcome based on competencies, blending academic and vocational education to answer market needs (Fomunyam, 2019).

The goal of the paper is to characterise edutainment as the modern approach towards teaching entrepreneurship. The specific goal is to present the teaching approach used in the Erasmus+ INKAMS project, run in the years 2017-2019, 
which can be qualified as edutainment. Descriptive methodology has been used to present both the structure of the presented approach and its mechanisms, as well as the requirements and expected benefits.

The structure of the paper is as follows: first, entrepreneurship has been characterized as one of the key competences in life-long learning. Then, various methods of teaching entrepreneurship are presented. The next section refers to experiential and active teaching methods, putting special emphasis on edutainment and movie education. The paper ends with conclusions and recommendations for teaching entrepreneurship to future generations.

\section{Entrepreneurship as a key competence}

Entrepreneurship is certainly a complex concept. As noted by A. Gaweł (2007), "economists who study entrepreneurship believe that there is a lack of a comprehensive and uniform theory of entrepreneurship or even its definition, which is the result of the multithreaded issues raised in its study and the interdisciplinary nature of this phenomenon". Similarly, we are dealing with ambiguity in the field of entrepreneurial education, dealing with many synonymous terms, such as: entrepreneurship education, entrepreneurship about education, education for enterprises, education in enterprise, etc. (Wach, 2013, 2015). Enterprise education is used more in the United Kingdom, referring to the broader concept of personal development, attitudes, mindset, skills and abilities; while entrepreneurship education, used in the US, covers mainly setting up a venture and becoming self-employed (Lackéus, 2015). Erkkilä (2000) proposed using the term entrepreneurial education to cover both enterprise and entrepreneurship education. The overview of the terms and definitions used in entrepreneurial education is presented in Figure 1. As can be observed, practice-oriented teaching is not used at the higher education level, which is a huge problem, since even graduates from business schools have no practical knowledge, as well as neither the skills or competencies on how to set up and run a company.

Another important thing visible in the Figure, but also in literature (Kwiatkowski, 2018), is the change in perceiving the concept of entrepreneurship as a competence, which now refers to:

a) knowledge, i.e. a set of facts, laws, theories, principles and experiences acquired or constructed independently,

b) skills, i.e. ability / readiness to use knowledge during the implementation of various types of tasks,

c) social competences, including the ability to design and shape one's own development, as well as autonomous and responsible participation in social and professional life. 


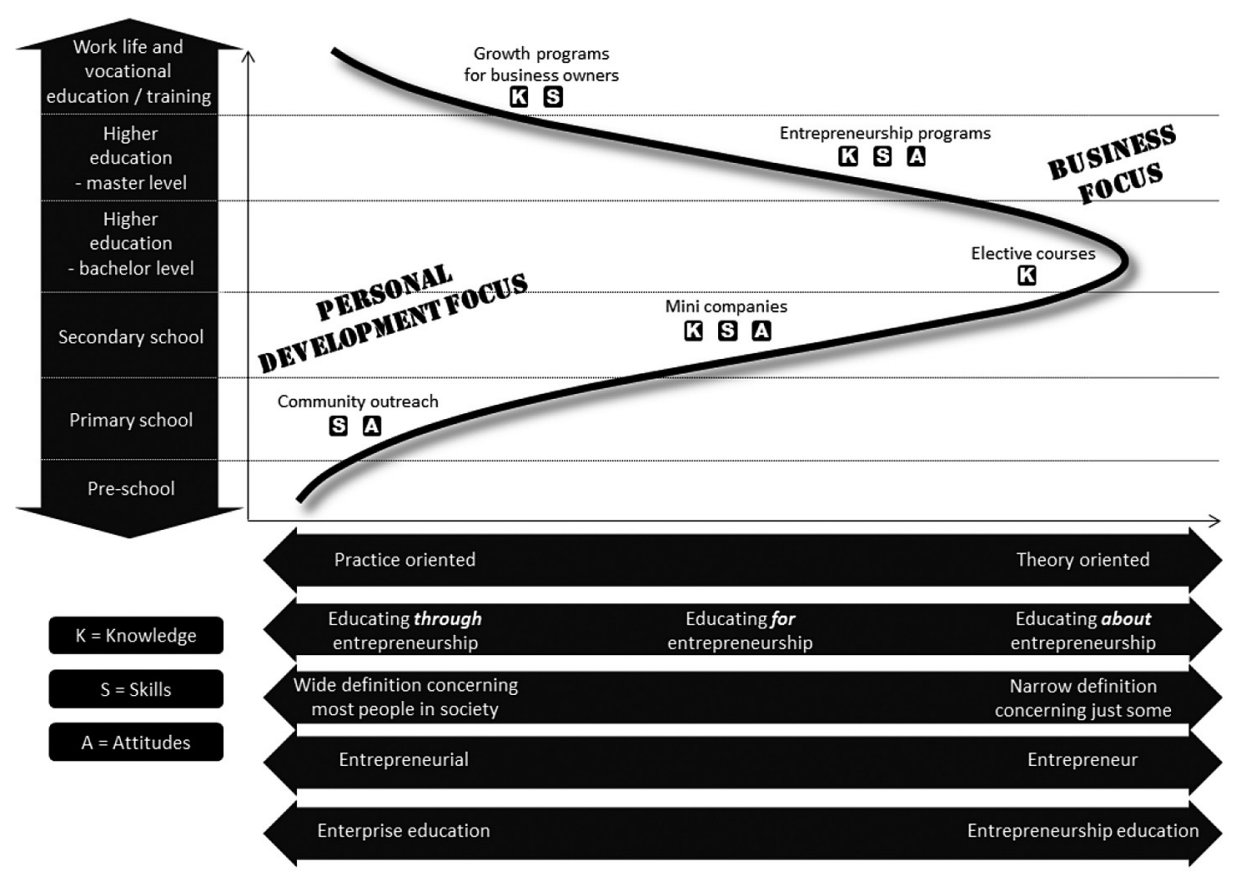

Figure 1 . The overview of terms and definitions currently used in entrepreneurial education

Source: Lackéus, 2015, p. 8.

As stipulated in the Council Recommendation of 22 May 2018, the key competencies for lifelong learning, essential knowledge, skills and attributes related to this competence are as follows (European Union, 2018):

- entrepreneurship competence requires knowing that there are different contexts and opportunities for turning ideas into action in personal, social and professional activities, and an understanding of how these arise. Individuals should know and understand approaches to planning and management of projects, which include both processes and resources. They should have an understanding of economics and the social and economic opportunities and challenges facing an employer, organisation or society. They should also be aware of ethical principles and challenges of sustainable development and have self-awareness of their own strengths and weaknesses,

- entrepreneurial skills are founded on creativity, which includes imagination, strategic thinking and problem-solving, and critical and constructive reflection within evolving creative processes and innovation. They include the ability to work both as an individual and collaboratively in teams, to mobilize resources (people and things) and to sustain activity. This includes the ability to make financial decisions relating to cost and value. The ability to effectively 
communicate and negotiate with others, and to cope with uncertainty, ambiguity and risk as part of making informed decisions is essential,

- an entrepreneurial attitude is characterised by a sense of initiative and agency, being pro-active, forward-looking, courageous and persevering in achieving objectives. It includes a desire to motivate others and value their ideas, having empathy and taking care of people and the world, as well as accepting responsibility taking ethical approaches throughout the process.

The second part of the definition of key competencies can be perceived as the characteristics regarding the necessary knowledge, skills and attitudes associated with a given competence. There are new references to proactivity (extremely important nowadays), the capacity for empathy, caring for other people and the world, as well as assuming responsibility and ethical attitudes. The issues of understanding economic processes, the ability to make financial decisions, effective communication and negotiating with other people, as well as dealing with uncertainty, ambiguity and risk as elements of the process of making informed decisions were also emphasized more.

The definition of entrepreneurship as a key competence has been further developed and proposed by the Thematic Working Group on entrepreneurship education, a body created by the European Commission (European Commission/ EACEA/Eurydice, 2016, p. 21; Thematic Working Group, 2015).

"Entrepreneurship education is about learners developing the skills and mind-set to be able to turn creative ideas into entrepreneurial action. This is a key competence for all learners, supporting personal development, active citizenship, social inclusion and employability. It is relevant across the lifelong learning process, in all disciplines of learning and to all forms of education and training (formal, non-formal and informal) which contribute to an entrepreneurial spirit or behaviour, with or without a commercial objective".

What is emphasised in this definition is the necessity to turn creative ideas into entrepreneurial actions. Secondly, entrepreneurship is not only related to economic activities and business creation, but more widely to all areas of life and society.

Building an effective strategy for shaping entrepreneurial competences in the education system from an early age requires adopting a fairly uniform approach to entrepreneurship, as it should be borne in mind that the recipients of this definition are not so much researchers, but primarily decision-makers in the field of education; authors of core curricula, teaching programmes and textbooks; teachers; and finally the students themselves.

A very interesting approach towards entrepreneurship can be found in the publication EntreComp: The Entrepreneurship Competence Framework (2016), which presents a shared definition of entrepreneurship as a competence, with the aim to achieve consensus among all stakeholders and to establish a bridge between the worlds of education and work. The EntreComp Framework is made up of 3 competence areas: 'Ideas and opportunities', 'Resources' and 'Into action'. Each area includes 5 competences, which together are the building blocks of 


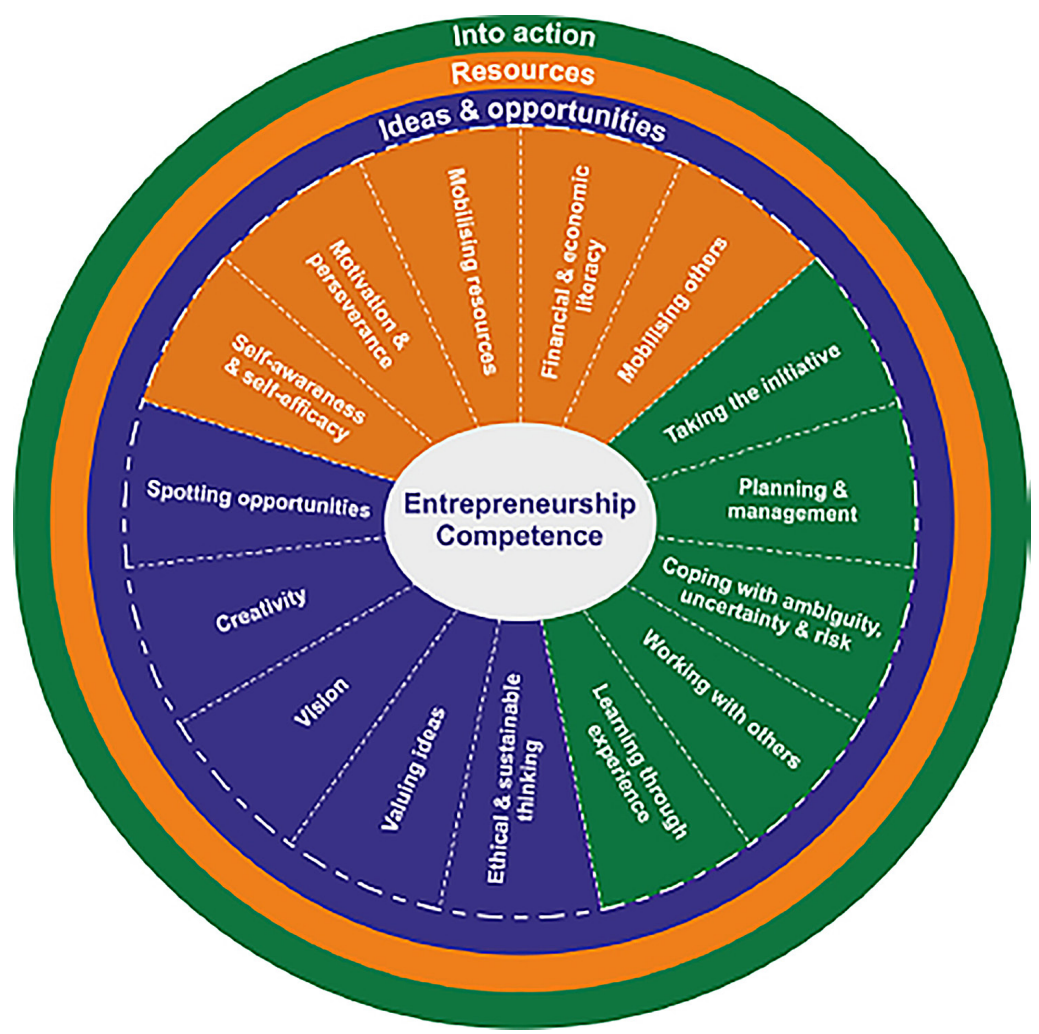

Figure 2. The EntreComp approach towards entrepreneurship as a competence

Source: Bacigalupo et al., (2016) EntreComp: The Entrepreneurship Competence Framework, JRCScience for Policy Report, European Commission, Seville, Spain, p. 8.

entrepreneurship as a competence. The framework develops the 15 competences along an 8-level progression model. Also, it provides a comprehensive list of 442 learning outcomes, which offers inspiration and insight for those designing interventions from different educational contexts and domains of application. EntreComp defines entrepreneurship as a transversal competence, which applies to all spheres of life: from nurturing personal development, to actively participating in society, to (re)entering the job market as an employee or as a self-employed person, and also to starting up ventures (cultural, social or commercial).

Learning outcomes are statements of what a learner knows, understands and is able to do after completion of learning. These statements can be designed and used for educational planning and curriculum development or for different types of accountability, such as legal or professional accountability (for the full list of learning outcomes developed by EntreComp, see the Appendix of the publication, pages 25-37). 
To keep up with the dynamics of changes in the perception of entrepreneurship in society and the economy, the academic community has to continuously and flexibly react, in particular to take an effort to adapt academic teachers to these changes.

\section{Teaching entrepreneurship - different pedagogical approaches}

As previously mentioned, the higher education system lacks modern, practice-based ways of teaching entrepreneurship. In most cases, the traditional theory-based teaching system dominates - a system in which various researchers, trainers and academics have been calling for change (see for example: Gibb, 1993, 2002, 2008; Kyrö, 2005; Wach, 2013, 2015; Neck et. al, 2014; Lackéus, 2015). As Lackéus (2015) points out, there is basically an argument between traditional, standardized, content focused, passive, single-based curriculum and new approaches, like progressive education (Reese, 2001; Löbler, 2006; Hayes, 2006), experiential learning (Kolb, 1984; Wach-Kąkolewicz, 2016), situated learning (Lave \& Wenger, 1991), service-learning (Meyers, 1999), problem / project-based learning (Helle et al., 2006), adult learning (Jarvis, 2006), cognitive apprenticeship (Collins, 2006) and social constructivist learning (Steffe, Gale, 1995). The most common features of these all approaches have been summarised below:

- progressive education: emphasis put on learning by doing; integrated curriculum focused on thematic units (here entrepreneurship); strong emphasis on problem solving, critical thinking; team work, development of social skills; collaborative learning projects; personalized learning; blended learning; emphasis on lifelong learning and social skills; tutor works not in the position of authoritarian, but rather as facilitator of the discussion or a group leader; movement for physical and mental health is recommended to create a sound body and mind,

- experiential learning: refers to the experience of the student or trainee; the student has to be actively involved in the experience and must be able to reflect on that experience, then use analytical skills to conceptualise the experience and finally make decision how to use new ideas gained from the experience - these four stages are the key elements of the Kolb learning cycle; people by their nature prefer a certain autonomous learning style affected by different factors and go through three stages of personal development, which are: acquisition (birth to adolescence) - acquiring basic abilities and cognitive structures; specialisation (schooling, early work and personal experiences of adulthood) - development of a particular specialised learning style affected and influenced by their own background; and finally, integration (from mid-career on) - expressing a non-dominant learning style in all life domains,

- situated learning: a model of learning in a community or practice - in this sense, the classroom is not determined and it can be a very random place; 
trainees or students become a part of the community through the learning process; they understand and experience the world, as well as knowledge, through the constant interactions by which they reconstruct their identity and evolve the forms of their membership in the community as their relationships change. In situated learning, no importance is given to the retention of the content; learning begins with people trying to solve problems; when learning is problem-based, people explore real-life situations to find answers, or to solve the problems,

- service learning: community oriented - combines learning objectives with community service in order to provide a pragmatic, progressive learning experience while meeting societal needs; it covers the following hands-on learning methods: volunteerism, community service and internship; trainees get tasks combined with delivering value for society, which enables them to practically use the theoretical knowledge acquired during formal education; the lessons learned from these situations are discussed during the lesson, creating a closed circle of school (theory) - practice (experience) - school (combining experience with theory),

- problem-based learning: students learn about a subject through the experience of solving an open-ended problem, usually in small groups with a tutor to facilitate discussion; students set their own goals and conduct their own research before coming to the group by individually searching for materials related to the topic; every person in the group has a role to play; fosters active learning, and also retention and development of lifelong learning skills; it encourages self-directed learning by confronting students with problems and stimulates the development of deep learning; it encourages students to activate prior knowledge and build on existing conceptual knowledge frameworks,

- adult learning: allows the use of prior, accumulated knowledge as well as work experience and adds to the learning experience; orientation to learning is problem-centred rather than subject-centred; motivation to learn is internal; it improves the social atmosphere and order,

- cognitive apprenticeship: the learner, while using cognitive tools and led by the teacher, can observe, enact, and practice implicit knowledge, thus achieving a successive approximation of mature practice; enculturates learners into authentic practices through activity and social interaction; the model consists of 6 stages: modelling (after observation of the teacher learners can model the desired performance); coaching (hints, feedback, modelling, reminders are provided); conceptual scaffolding (teachers support the learner in accomplishing tasks); articulation (covers any method of getting students to articulate their knowledge, reasoning, or problem-solving processes); reflection (the learner reflects on the problem solving task while comparing their own way with the expert one); and finally exploration (students are encouraged to explore new ways in which knowledge or skill can be used),

- constructivist learning: learners are encouraged to use knowledge derived from their own background in the educational process; emphasizes the impor- 
tance of the learner being actively involved in the learning process; learners should learn to discover principles, concepts and facts for themselves, hence the importance of encouraging guesswork and intuitive thinking in learners; learners gain meanings through the interactions with each other and with the environment they live in; they gain additional experience due to interactions with the group and community.

The presented approaches are more individualised, active, process based, collaborative, experiential and multidisciplinary. They require much greater student involvement, but also, above all, proper teacher preparation. They force you to go beyond patterns and open yourself to new experiences, far beyond the comfort zone of theoretical considerations and models. When using these approaches in entrepreneurship education, it would be necessary to implement activities such as: apprenticeships in companies, participation in real project teams, establishing and conducting real companies, meetings and discussions with business practitioners, finding and solving real economic problems in the form of case studies, discussions and giving opinions on legal acts, solutions and regulations introduced by the government; meetings and discussions with local communities, participation in conferences and business symposia, competitions for practical solutions to economic problems, writing business plans, feasibility studies, etc. There is a real need for more interactive learning approaches in which the teacher acts as a moderator rather than a lecturer. An essential element in building entrepreneurial skills is crossing the boundaries between disciplines and multidisciplinary cooperation. Because academic teachers often lack practical preparation, the solution may be the involvement of real entrepreneurs in teaching entrepreneurship. Unfortunately, there are very few cases where business people are truly engaged in teaching. European higher education institutions are not sufficiently involved and effective in working with graduates who are successful in business ventures and who could bring knowledge and funds. Companies unwillingly accept students for an apprenticeship, since they have no capacity to take care of apprentices and the value added from their presence is usually low. The mobility of teachers and academic scientists between higher education and business institutions is also generally low and is not actively promoted, sometimes even discouraging such activity, and even prohibiting it. At the same time, going outside the school walls and changing the environment are limited by legal regulations or lecturer's discomfort. Another obstacle is certainly the focus of academic teachers on research that is the basis for professional promotion. The implementation of new solutions, going beyond the usual teaching patterns, the search for innovative solutions is too often seen as a "waste of time". 


\section{Edutainment as a modern way of teaching entrepreneurship}

As the world is dealing with a generational change at universities, perception and cognitive abilities change. New generations bring to the classroom a new hierarchy of values and their own style of work, beliefs, as well as new needs and opportunities. Digital technology has a powerful impact on how the brain shapes and functions. Under the influence of electronic media and new forms of virtual socialization, new ways of brain activity and new skills are emerging. Students are not willing to read paper books as much as before. They expect a change in the form of communication and adapt educational content to their perception. The answer may be edutainment being a form that comes from merging education and entertainment. It is a form of entertainment designed to educate and train, but also to amuse. The main purpose of edutainment is to promote student learning through exploration, interactivity, community experience, team work, trial and error, and repetition in such a way that students get so lost in the fun that they do not realize they are learning at the same time. The digital era, portrayed as the 3rd and 4th industrial revolutions, and the internet have affected the traditional educational environments and enabled implementation of a large variety of edutainment types (video, social media, virtual games and simulators) in the learning process, thus radically transforming the educational paradigm by strengthening the relationship between learning, new media and play (Zorica, 2014). The educational process has become more challenging and much more complex, requiring completely new strategies and approaches in the classroom, and also much higher engagement from academic staff. The popularity of various web tools or visuals, like mind maps, pins, social media, podcasts, and Youtube has enlarged the availability of the educational toolbox, while at the same time changing the way people acquire knowledge and perceive the construction of the educational process. Turning to education for fun and equipping it with internet tools is a trend which dominates many aspects of our lives. A new form is given to the message, which is set in a new virtual environment, a "virtual edutainment environment" (VEE), where interaction with the consumer takes place. A VEE is an environment in which one or more consumers experience the recreated message. This message is delivered in real time. In this context, users may interact with each other, but what is essential is that the information be elaborated in one complex way, utilizing multimedia tools in order to affect the consumer's senses. Hence, consumers are immersed in a deep experience of edutainment (Addis, 2005). Edutainment is an evolving alternative to traditional educational methods. It can be organized in different ways. White (2003, cited in Harnani \& Nor Zuhaidah, 2010), categorized edutainment in four different groups, which are:

- location-based edutainment, which can be divided into two categories: interactive and participatory, where children can play and participate in games; and non-interactive and spectator, where children can just be seated and explore (movies, science shows, museums and zoos), 
- edutainment on purpose in which content consists of informal education, which is to improve learners' life control; and skills education which is to give experiences, like simulations,

- edutainment by target group, which includes motivation-oriented (learners who have the same interest), and age-oriented (learners who have the same age),

- edutainment by type of media: edutainment on TV - including comedy drama, historical drama, comedy sketches, skill learning and travel programmes; computer edutainment - including adventure, quiz, role-playing, strategy and simulation game types, as well as experimental drama; edutainment on the Internet - including tele-teaching and tele-learning systems, and web-based educational systems; and interactive television. These types of edutainment use the advent of digital television to provide interactivity via software and hardware and connect with other telecommunication systems.

Zorica (2014) suggests a further division in this typology by dividing edutainment into four categories: video, web 2.0, games and virtual worlds; seeing advantages from using these kind of tools as development of generic skills, enabling education to be based on social constructivist theory, influencing student motivation and bridging the gap between theory and practice by providing opportunities for gathering experience, sharing knowledge and providing an authentic context along with activities for learning by doing. Aksakal (2015) points out the following characteristics of edutainment:

- entertainment and interaction, which is thought to be missing in education, attracting learners' attention due to being gamified,

- combining education and entertainment and increasing learners' excitement and enthusiasm to teach them subjects and information that is hard to learn,

- acquiring learning more easily by making the subjects and information that will be taught more enjoyable,

- attracting learners' attention and gaining the permanence of learning by the rousing of learners' feelings,

- making the internalization of difficult subjects easy using methods of simulation or graphs and visual methods, like in real life,

- teaching how to use resources and methods regarding the value of life by combining educational aims and measurement,

- teaching how individuals in learning environments apply their own knowledge,

- demonstrating how individuals understand or internalize what they learn,

- used in order to teach to learners combining what they perceive or evaluating what they learn,

- finally, it provides learners with a good time in the process of creating and experiencing.

Edutainment is an attractive method of teaching, since it encourages personalized learning, enhances creativity and visualisation, transforms a conventional 
classroom into a smart classroom, improves interactive and collaborative teaching and learning methods, promotes a digital culture and provides technological tools for educators. Thinking about edutainment in teaching entrepreneurship should relate to using virtual reality in the educational process, like for example, business simulations, strategic games, using all kinds of interactive media (videos, Youtube transmissions, podcasts), video case studies, providing chatrooms and teleconferences with real entrepreneurs, producing films and webinars. Edutainment can also serve as a tool for building entrepreneurial identity. As Schneider (2019, p. 10) points out, "the opportunity and necessity to interact with other avatars and stakeholders in a virtual environment enables a person to acquire information and support, social validation through social standards as reference points for their aspects of the self, and to identify with other successful entrepreneurs. Forming a new entrepreneurial virtual environment by a constellation of cherished objects, spaces and characters also furthers the process of self-reflectivity and significance making as an innovator". The development of role-playing in society, as well as in working groups through relationships, social validation and comparison, plays a crucial role in education and also being very important for the self-development of every entrepreneur.

\section{Method of teaching entrepreneurship developed by CONFORM S.c.a.r.I and tested by the INKAMS Partnership ${ }^{1}$}

The INKAMS project aims were to realize, pilot, disseminate and systematize a new University-based learning programme focused on International Sales and Key Account Management (KAM). This was supposed to be an integrated and permanent European framework which, through changing the methodological paradigm, would enable the development of International Sales and Key Account Management skills, with innovative, interactive modes that are adaptable to business and individual needs. The expected results of this project were:

- the design and application of a new university learning curriculum, based on international sales and KAM,

- digital integration in learning, facilitating access to a variety of OERs, developed with visual thinking techniques,

- the adoption of a European model of interactive university teaching that can help methods, tools, solutions and learning situations to evolve and enhance the level of students' management culture and the valorisation of new talents for International Sales and KAM,

\footnotetext{
INKAMS - International Key Account Management and Sales (2017-1-IT02-KA203-036707), project cofounded by the Erasmus + Programme of the European Union within a Consortium led by Università Politecnica delle Marche in Italy in years 2017-2019 (prof. Silvio Cardinali as project manager). Poznań University of Economics and Business was a member of the Consortium.
} 
- the building of stable links between universities, businesses and territories, and realizing systems of relationships where sharing of knowledge, experiences and technologies guarantees value co-creation and the construction of a European-wide relational capital,

- developing forms of social/collaborative learning opportunities facilitated by the creation of the CLIMA learning environment to develop skills and manage sales processes and increase SME sales volumes,

- creating, through online social networking spaces, networking opportunities to aggregate ideas, experiences and skills,

- the involvement of a group of 85 students in the testing of a training course based on the following three dimensions:

- cognitive (learning by thinking),

- operative (learning by doing),

- behavioural (learning by acting).

From the focus perspective of this paper, the most important was introducing a new learning approach, developed by CONFORM S.c.a.r.l and tested by the INAKMS Partnership. The methodology has been based on the three dimensions mentioned above.

\section{Learning by thinking}

This element referred to the traditional, cognitive aspect of the learning process. Partners prepared Open Educational Resources, which were created while bearing in mind:

- pleasure in use, taking care of the graphical interface of the Learning Objects and balancing the stimuli affecting the different sensory channels,

- experiential approach, with the representation of typical situations of organizational behaviour, in order to lead the learner to reflect,

- multiplicity of solutions adopted, integrating different types of multimedia resources (2D/3D animations, audio/video tutorials, e-books, assessment tests).

Materials were prepared in the form of a presentation, with the lecturer performing in a virtual office with subtitles in different languages, associated by additional interactive materials (PDFs, videos). Students were supposed to login to the platform, watch the materials and acquire skills and abilities by completing the test.

\section{Learning by doing}

This part of the learning process referred to the implementation of a cognitive analysis aiming to understand the ways and means by which SMEs can be guided 
in defining their strategic routes to improve sales processes, based on the current and prospective development potential of companies that is not fully exploited, in terms of commercial performance. A questionnaire was prepared to enable the audit of the company in the following areas:

- company technological and commercial know-how,

- communication and relationships with key customers,

- reference market and sales network,

- articulation of commercial processes,

- methods and criteria used,

- income and competitive performance,

- monitoring and reporting systems.

This audit was a foundation for a further check-up. Students received the results of the survey; they were supposed to analyse them under the supervision of the lecturer or tutor from the chamber of commerce and then meet with the company representative for a further deep interview. After those activities, students were supposed to prepare a final report. The aim of this part of the learning process was to allow the beneficiaries to strengthen their possession and exercise of the distinctive skills of sales and KAM processes; thus gaining greater awareness of the specialization they have achieved, enabling them to carry out a highly-skilled professional search/action activity divided into the following steps:

- definition of intervention priorities to align change with sales development business strategies,

- definition of the types of commercial and competitive development projects on foreign markets that can be activated and position them in key customer matrix / contact channels and technologies,

- development of a feasibility plan indicating the innovative commitment required and correlated resource requirements,

- identification of the availability of existing resources and skills to support the process of sales innovation and strategic management of key clients,

- identification and sharing of sales and competitive development projects to be implemented with relative allocation of resources,

- drafting of the project implementation plan with an indication of activities, outputs, key skills and realization times.

In particular, analysis conducted through desk research and company checkups will help students to gather useful information to map the strengths, weaknesses, threats, and opportunities to seize to understand how to guide SMEs in defining strategic routes to:

- define strategies by setting objectives and guidelines,

- map the competitive starting point,

- use different segmentation criteria,

- conduct a competitor analysis,

- identify critical success factors,

- define one's value proposition, 
- redesign the business model,

- choose key customer management strategies and short- and medium-term goals,

- apply strategic positioning by defining times and actions,

- make the sales plan a central and shared reference point.

- translate the strategy into a sales plan that contains specific actions regarding top clients.

\section{Learning by acting - movie education ${ }^{2}$}

The company check-up was only a preparatory session to create educational short films, which enabled seeing the beneficiaries engaged in drafting the scripts to be interpreted to stage the typical situations of commercial processes and the relationships with strategic clients.

The realization of short educational films was based on the edutainment model, called "movie education", as a result of a project that CONFORM S.c.a.r.l (Partner of the INKAMS project) developed in the Research \& Development program of the Italian Ministry of Economic Development. One can find more information on the company's websites dedicated to that model, for example at https://conform.it/movie-education/, or watch an interview with the company's CEO, Alfonso Santaniello (https://vimeo.com/373095316), which describes the model in its characteristic aspects. Thanks also to the support of images taken from several short film / web series, realized in various projects at national and international level. An application of movie education to entrepreneurship can be seen in the 4 episodes of the web series "5TO Succeed" (https://5tosucceed. conform.it/en/). The "5TO Succeed" interactive training series combines entertainment and learning, with the aim of developing and consolidating economic-financial and entrepreneurial skills, together with the negotiating, relational, decision-making and creative qualities that an aspiring entrepreneur must mobilize in the processes of business creation and management.

The Web Series, exploiting the potential of new digital technologies, allows users to interact with the film while watching the 4 episodes, involving them and directing them to consult the different in-depth materials provided at various points in history, to expand and consolidate knowledge, as well as the skills and behaviours that characterize entrepreneurial skills in an integrated way. Four iconic, fun and educational episodes tell the story of a group of young people struggling with the start of a new business initiative.

This pedagogical approach, combines didactics and entertainment through movie education methodology, to convey know-how in film mode and to evolve learning methods, so as to:

- foster experience-based learning,

2 The Author would like to express gratitude for all the materials submitted by CONFORM S.c.a.r.1 and personal contribution of Mr Alfonso Santaniello (CEO of the Company) for this section. 
- combine emotional and cognitive aspects,

- stimulate interest and motivation to learn,

- allow one to capture the virtuous behaviours to be emulated and the mistakes to avoid,

- transmit meaningful messages with a strong educational impact, structured according to a cause effect logic, where a story generates other situations, according to the intertext mechanism, promoting networked knowledge (connective knowledge) with dialogic comparison, critical thinking and a search for new interpretations.

- exploiting the potential of new digital technologies, which allows for directing the student towards technical insights, which can be accessed through the use of interactive tools.

Over the years, the experiments of the Movie Education Model have been different and in different learning contexts, nationally and internationally. This guaranteed CONFORM S.c.a.r.l. solutions that are state aggregated in two distinct areas, that of the Short Movie Laboratory and that of Audiovisual Production.

With the "Short Films Laboratory", the training objective is the state of the students' ability to:

- stage the theoretical notions learned during the courses, through their direct participation in the writing of a script for the production of a video capable of making the acquisition of know-how by other beneficiaries lighter;

- experiment and acquire video editing techniques;

- put into practice the examples related to the topics covered, through simulations linked to the interpretation of specific professional roles.

With the Audiovisual Productions, high-value short films, web series, films or docufilms have been established with the interest of involving and attracting the viewer, who is at the same time also a student, through a learning model capable of contaminating other characteristic elements of a entertainment product with the educational, thus allowing it to take advantage of different training contents.

This happens thanks to the presence within the filmic moments of:

- keywords, which, written in the screenplay, are interpreted by the actors to make the spectator more impressed,

- characters and situations that are staged using the use of the film plot to show key events, and are useful for educating the student in the correct way to act in specific moments and contexts.

Through the interactivity connected to the "keywords" recited by the actors, the viewer has the opportunity to access in-depth sections, where teaching materials of various formats (documents, videos, audio, images or links to external sites and anything else is possible) will contribute to the deepening of the contents and the treated themes, therefore making his learning more complete and more performable. 
The update of the CONFORM S.c.a.r.l. Movie Education model represented a fundamentally important element for the INKAMS project, from the definition of the curriculum to its experimentation in the field, with teachers and trainers of the partnerships involved in learning mobility to understand and acquire the methodological bases of Movie Education, and with the students beneficiaries of the Improvement Laboratory of Storytelling.

The operating framework has been divided into the following didactic, interdependent and consequential steps, which have made it possible to standardize the approach in all the countries of the partnership. The steps are to (Figure 3):

- present the methodology of film education and storytelling,

- provide the Improvement Laboratory of Storytelling,

- support learners in storyboard development,

- assist them in shooting and editing,

- evaluate the functions of the product they have created.

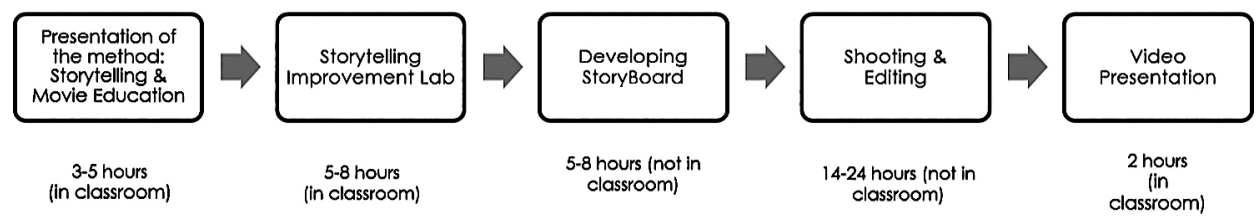

Figure 3. The operating framework Source: CONFORM's materials.

For each of the steps, an average duration was suggested for carrying out the planned activities.

The Improvement Laboratory of Storytelling sessions, provided by the trainers following mobility in the partnership countries, allowed the evaluation of the didactic effectiveness of movie education, testing its adaptability to the different territorial contexts of the partnership and to the different cultural sensitivities of the beneficiaries. This aspect is of significant value for implementing a strategy for the dissemination and dissemination of results that can favour its transfer and replicability.

Students from Italy, Poland, Bulgaria, Spain, and Slovenia benefited from the workshops, making themselves the authors and actors in the realization of some shorts on the key themes of the international sales process.

The students, divided into groups of $6-8$ people, have (Figure 4):

- defined the idea,

- chosen the theme on which to base the story, based on the 12 OERs used in the e-learning mode,

- used the equipment provided by the teachers,

- defined the roles of each member of the group,

- described the main steps of the story (behaviour, conflict, change, location, etc.),

- drafted a synopsis. 


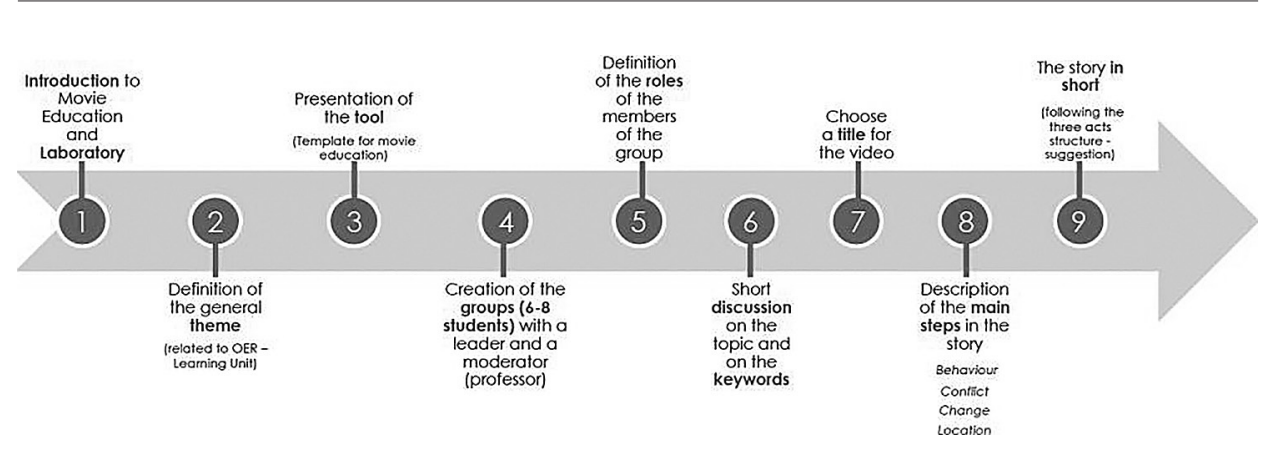

Figure 4. The movie education learning process Source: CONFORM's materials.

Once the idea was defined, the students drafted the storyboard, graphically representing the story, before writing the script and filming and editing the product.

Altogether, in the program in Poland, 50 students took part, recording 9 films (also 20 Students in Slovenia, 60 in Italy, 63 in Spain and 18 in Bulgaria). Students were trained in movie education, especially in storytelling and script writing. Some examples were also showed to students about how to record movies; additionally, further materials were placed on Moodle to enhance the process. Students were informed that they were supposed to refer to materials placed on the e-learning platform in their scripts. Choosing the language used in the movie was optional for all groups, but English was appreciated. Students were informed about the possibility of protecting their own image and they generally claimed their right to it. According to the disclosure agreement, 8 out of 9 groups refused to make the movie public.

According to the first impressions of the teacher, students were very angry with introducing this teaching tool. This was completely new to them; they did not feel comfortable in the new reality. They also barely perceived the process as didactically useful. They did not see any value in the process, and perceived it as long, tedious and monotonous, in a very busy period of their life. They did not express their opinions publicly, but in the lobby, and less formal conversations; they complained about all the requirements. However, once the process had been completed, their reactions were different and opposite. They found a kind of joy, which was visible in the recorded clips. Considering the pros and cons of this learning activity one could say the following (see Table 1).

The whole learning process was introduced into the classroom for the first time. As it was a completely new process, a number of errors and shortcomings were unavoidable. However, the positive effects seem to indicate that it is an attractive and didactically effective way of encouraging entrepreneurship education. Students devote less time to studying theoretical issues, treating them only as a necessary background to structure problems and build the basis for the conceptualization of observed experiences. At the same time, by working and solving real economic issues, they learn practical things, and while preparing films, they play and develop cooperation and teamwork skills. In this way, they fit more into 
Table 1. Basic pros and cons of movie education

\begin{tabular}{ll}
\hline Pros (advantages) & Cons (disadvantages) \\
\hline $\begin{array}{l}\text { Engaging, addictive process, that } \\
\text { brings joy. }\end{array}$ & $\begin{array}{l}\text { Limited technical resources (necessity to train } \\
\text { not only about storytelling, but also technical } \\
\text { aspects of recording). }\end{array}$ \\
$\begin{array}{ll}\text { Greater assimilation of knowledge due } \\
\text { to direct and personal involvement. }\end{array}$ & $\begin{array}{l}\text { Very hard to tell a good story in a few minute } \\
\text { long film. } \\
\text { Greater opportunity to cooperate with } \\
\text { the group. }\end{array}$ \\
\hline
\end{tabular}

Source: Author's own.

experiential learning and problem-based learning as they examine a real company problem; then conceptualize it on the basis of the background and initial knowledge they possess; and finally try to test those concepts while proposing solutions that can be implemented in practice. And all this by way of combining knowledge and entertainment.

\section{Final remarks}

The entrepreneurship concept is multidimensional and very broad. Moreover, it is subject to constant and rapid changes. Entrepreneurship education in higher education seems to not follow the rapid changes in the socio-economic environment. If one adds to this all the technological and internet transformations visible within the $3 \mathrm{rd}$ and 4 th industrial revolutions, the delay in adjusting to reality is even more apparent. Traditional learning processes are not sufficient for educating future entrepreneurs, and the call for change is visible not only in the literature but from the direct beneficiaries - students and trainees. Students require completely new practice-based approaches inclined more towards contact with real businesses. Change is required and one of the possible ways is introducing completely new approaches on the basis of modern pedagogical approaches, especially capturing elements of edutainment, which is close to the heart of the newer generations coming to the universities. The advantage of edutainment is its high efficiency in the transfer of knowledge and skills. Compared to the traditional approaches, it is a much more intuitive, collaborative, process-based and visually attractive. The use of this tool in the education process accelerates and consolidates the desired (or created) social attitudes. Minds are more open to educational messages when recipients do not realize that they are actually learning. Integrating all elements of the learning process - cognitive, operational and participating (movie education) - may bring about a synergy effect, which simultaneously bridges traditional and modern approaches and connects it into one educational strategy. Although experience of this strategy of teaching entrepreneurship seems to be promising, it requires further observations, and first of all, methodologically designed research heading towards comprehensive evaluation and assessment. 


\section{References}

Addis, M. (2005). New technologies and cultural consumption - edutainment is born! European Journal of Marketing, 39, 7/8, 729-736.

Aksakal, N. (2015). Theoretical View to The Approach of The Edutainment. 5th World Conference on Learning, Teaching and Educational Leadership, WCLTA 2014. Procedia - Social and Behavioral Sciences, 186, 1232-1239.

Bacigalupo, M., Kampylis, P., Punie, Y., \& Van der Brande, G. (2016). Entre Comp: The Entrepreneurship Competence Framework. Seville: European Commission.

Collins, A. (2006). Cognitive apprenticeship. In R. K. Sawyer, The Cambridge handbook of the learning sciences. Cambridge: Cambridge University Press.

Erkilä, K. (2000). Entrepreneurial education: mapping the debates in the United States, the United Kingdom and Finland. Abingdon: Taylor \& Francis.

European Commission/EACEA/Eurydice. (2016). Entrepreneurship Education at School in Europe. Luxembourg: Publications Office of the European Union.

European Union. (2018). Council Recommendation of 22 May 2018 on key competencies for lifelong learning. Official Journal of the European Union.

Fomunyam, K. G. (2019). Education and the Fourth Industrial Revolution: challenges and possibilities for engineering education. International Journal of Mechanical Engineering and Technology, 10, 08.

Gaweł, A. (2007). Ekonomiczne determinanty przedsiębiorczości. Poznań: Wydawnictwo Akademii Ekonomicznej.

Gibb, A. A. (1993). Enterprise Culture and Education Understanding Enterprise Education and Its Links with Small Business, Entrepreneurship and Wider Educational Goals. International Small Business Journal, 11-34.

Gibb, A. A. (2002). In pursuit of a new 'enterprise' and 'entrepreneurship' paradigm for learning: creative destruction, new values, new ways of doing things and new combinations of knowledge. International Journal of Entrepreneurship Education, 4, 233-269.

Gibb, A. A. (2008). Entrepreneurship and enterprise education in schools and colleges: insights from UK practice. International Journal of Entrepreneurship Education, 6, 48.

Harnani, M. Z., \& Nor Zuhaidah, M. Z. (2010). The Effects of Editainment towards Student's Achievements. Proceedings of Regional Conference on Knowledge Integration in ICT 2010 (pp. 64-72). https://www.academia.edu/489354/THE_EFFECTS_OF_ EDUTAINMENT_TOWARDS_STUDENTSACHIEVEMENTS.

Hayes, W. (2006). The progressive education movement: Is it still a factor in today's schools? Rowman \& Littlefield Education.

Helle, L., Tynjälä, P., \& Olkinuora, E. (2006). Project-based learning in post-secondary education - theory, practice and rubber sling shots. Higher Education, 51, 287-314.

Jarvis, P. (2006). Towards a comprehensive theory of human learning. New York: Routledge.

Kolb, D. A. (1984). Experiential learning: Experience as the source of learning and development (Vol. 1). Englewood Cliffs, New York: Prentice-Hall.

Kwiatkowski, S. M. (2018). Kompetencje przyszłości. In S. M. Kwiatkowski, Kompetencje przysztości (pp. 14-29). Warszawa: Fundacja Rozwoju Systemu Edukacji.

Kyrö, P. (2005). Entrepreneurial learning in across-cultural context challenges previous learning paradigms. In P. Kyrö \& C. Carrier, The Dynamics of Learning Entrepreneurship in a Cross-Cultural University Context. Hämeenlinna: University of Tampere.

Lackéus, M. (2015). Entrepreneurship in Education. What, Why, When, How. Paris: OECD.

Lave, J., \& Wenger, E. (1991). Situated learning: Legitimate peripheral participation. Cambridge: Cambridge University Press. 
Löbler, H. (2006). Learning entrepreneurship from a constructivist perspective. Analysis \& Strategic Management, 8, 19-38.

Meyers, S. (1999). Service learning in alternative education settings. The Clearing House, 73, 114-117.

Neck, H. M., Greene, P. G., \& Brush, C. G. (2014). Teaching Entrepreneurship: A Practice-Based Approach. Edward Elgar Publishing.

Reese, Q. (2001). The Origins of Progressive Education. History of Education Quarterly, 41, $1-24$.

Schneider, K. (2019). How to promote entrepreneurial identity through edutainment? Journal of Entrepreneurship Education, 22, 3, 1-12.

Spector, J. M. (2016). Foundations of educational technology: integrative approaches and interdisciplinary perspectives. Routledge.

Steffe, L. P., \& Gale, J. E. (1995). Constructivism in education. Lawrence Erlbaum Hillsdale. Thematic Working Group. (2015). Thematic Working Group on Entrepreneurship Education. European Union.

Wach, K. (2013). Edukacja na rzecz przedsiębiorczości wobec współczesnych. Przedsiębiorczość-Edukacja, 9, 246-257.

Wach, K. (2015). Przedsiębiorczość jako czynnik rozwoju społeczno-gospodarczego: przegląd literatury. Przedsiębiorczość-Edukacja, 11, 24-36.

Wach-Kąkolewicz, A. (2016). Constructivist Approach in Teaching in Higher Education. In A. Wach-Kąkolewicz \& R. Mufoletto, Perspectives on Computer Gaming (pp. 11-20). Poznań: Bogucki Wydawnictwo Naukowe.

White, R. (2003, December 2019). White Hutchinson Leisure \& Learning Group. https://www. whitehutchinson.com/leisure/articles/edutainment.shtml\#1.

Zorica, M. B. (2014). Edutainment at the Higher Education as a new element for the learning success. Proceedings of EDULEARN 14 Conference. Barcelona. 